\title{
Sifat Organoleptik Bakso Pada Berbagai Rasio Perbandingan Daging Sapi Dan Babi
}

\author{
Charliany Hetharia, Yerrynaldo Loppies, Herman Handu \\ Universitas Victory Sorong, Indonesia \\ janethnadin270416@gmail.com
}

\begin{abstract}
Abstrak
Penelitian ini bertujuan untuk mengetahui rasio perbandingan daging sapi dan babi yang disukai serta pengaruhnya terhadap sifat organoleptik bakso yang dihasilkan. Penelitian ini menggunakan rasio presentasi sebagai perbandingan antara kedua daging tersebut yaitu P1 (75\% daging sapi: 25\% daging babi), P2 (50\% daging sapi: 50\% daging babi), P3 (25\% daging sapi: 75\% daging babi), K1 (kontrol bakso sapi) dan K2 (kontrol bakso babi) dan 35 panelis sebagai ulangan. Peubah yang diamati adalah sifat organoleptik berupa warna, aroma, tekstur, rasa dan kekenyalan. Data yang diperoleh dianalisa dengan metode Kruskal-Wallis. Hasil analisis menunjukkan, perlakuan rasio perbandingan daging sapi dan babi berpengaruh nyata pada taraf $(\mathrm{P}<0.05)$ terhadap sifat organoleptik warna dan kekenyalan tetapi tidak berpengaruh terhadap sifat organoleptik aroma, rasa dan tekstur. Berdasarkan hasil tersebut diatas maka dapat disimpulkan bahwa rasio perbandingan daging sapi dan babi yang disukai serta berpengaruh terhadap sifat organoleptik adalah P2 (50\% daging sapi: $50 \%$ daging babi)
\end{abstract}

Kata kunci: bakso, daging babi, daging sapi, rasio

\section{PENDAHULUAN}

Bakso merupakan satu produk olahan berbahandasar daging yang sangat disukai dan digemari oleh masyarakat. Nordiansyah dkk, (2015) menyatakan bahwa bakso mempunyai kandungan protein, mineral serta vitamin yang tinggi). Bakso yang umumnya beredar dipasaran adalah bakso daging sapi, namun demikian tidak menutup kemungkinan untuk membuat bakso dari kombinasi daging sapi dengan daging lainnya, seperti daging babi. Daging babi memiliki kandungan gizi yang hampir sama dengan daging sapi (Lawrie, 2003).

Di Papua Barat, daging babi biasanya diolah secara tradisional dengan dibakar. Selama proses pembakaran, daging tersebut memiliki zat karsinogen yang lebih tinggi dibandingkan dengan daging yang diolah dengan direbus, apalagi bila dimasak setengah matang (Sunarlim, 2000). Selama proses pembakaran daging, zat-zat gizi yang terdapat dalam daging keluar sehingga menyebabkan berkurangnya kandungan gizi daging tersebut. Pembuatan bakso dengan mencampur daging sapi dan babi merupakan salah satu upaya difersifikasi pangan untuk pengembangan olahan daging babi oleh masyarakat agar lebih moderen serta juga meningkatkan nilai jual dari daging babi. Untuk itulah penulis melakukan penelitian ini dengan tujuan agar dapat mengetahui rasio antara daging sapi dan babi yang disukai ditinjau dari sifat organoleptiknya serta dapat mengetahui 
Doi http://doi.org/md.v13i1.191 pengaruh rasio antara daging sapi dan daging babi terhadap sifat organoleptik bakso yang dihasilkan.

\section{METODE PENELITIAN}

Penelitian ini dilaksanakan dari bulan Juli sampai September 2020 di Laboratorium Program Studi Peternakan Fakultas Ilmu Pertanian dan Lingkungan Universitas Victory Sorong. Pelaksanaan penelitian dimulai dengan memisahkan lemak dan jaringan ikat pada daging sapi dan babi kemudian, dicuci bersih dan dipotong kecil-kecil. Selanjutnya ditimbang sesuai dengan rasio presentase perbandingan untuk perlakuan yaitu P1 (75\% daging sapi: 25\% daging babi), P2 (50\% daging sapi: 50\% daging babi), P3 (25\% daging sapi: 75\% daging babi), K1 (kontrol bakso sapi) dan K2 (kontrol bakso babi). Daging yang telah dibersikan dan ditimbang sesuai dengan perbandingan perlakuannya kemudian dimasukkan ke dalam food processor kemudian ditambahkan es batu, garam dan STPP dan daging digiling selama dua menit. Setelah dua menit kemudian ditambahkan tepung tapioka, bawang putih dan merica serta es batu llu digiling selama satu menit. Setelah adonan tercampur rata, kemudian disimpan dalam refrigerator dengan suhu $10^{\circ} \mathrm{C}$ selama 10 menit. Selanjutnya adonan dikeluarkan dari refrigerator kemudian dibentuk menjadi bulat lalu direbus dengan air pada suhu $90^{\circ} \mathrm{C}$ hingga bakso terapung dan matang selama 15 menit (Sunarlim, 2000).

Pada Penelitian ini variabel yang diamati adalah uji organoleptik. Uji organoleptik menggunakan 5 kriteria yaitu warna, rasa, tekstur, aroma dan kekenyalan (Nordiansyah dkk, 2015).

a. Warna; Sampel bakso diambil dan dibelah menjadi dua dan diletakan para piring pengujian, kemudian sampel diamati untuk mengetahui warna.

b. Aroma; Sampel bakso diambil dan dibelah menjadi dua dan diletakan para piring pengujian, kemudian dicium atau dihirup aromanya.

c. Tekstur; Sampel bakso diambil dan dibelah menjadi dua dan diletakan para piring pengujian, kemudian sampel dipegang untuk mengetahui tekstur dari sampel.

d. Rasa; Sampel bakso diambil dan diletakan pada piring pengujian untuk dicicipi oleh indra pengecap guna mengetahui rasa dari sampel. Setiap kali setelah panelis melakukan pengujian rasa, penelis diberikan air untuk diminum guna menghilangkan rasa pertama, selanjutnya baru dilanjutkan pengujian berikutnya.

e. Kekenyalan; Sampel bakso diambil dan diletakan pada piring pengujian, kemudian sampel dipegang untuk mengetahui tingkat kekenyalannya.

Data yang diperoleh dari hasil pengukuran dianalisis dengan Uji Kruskal Wallis dengan rumus sebagai berikut (Irmawaty, 2016):

$$
K=(N-1) \frac{\sum_{i=1}^{g} n i(\tau-1}{\sum_{i=1}^{g} \sum_{j}^{g}(\tau i j-1)^{2}}
$$

Dimana:

$\eta \mathrm{i}=$ Jumlah pengamatan dalam kelompok

Rij $=$ Peringkat pengamatan $\mathrm{j}$ dari kelompok $\mathrm{i}$

$\mathrm{N}=$ Jumlah pengamatan di semua kelompok 


\section{HASIL DAN PEMBAHASAN}

Tingkat kesukaan panelis terhadap bakso rasio perbadingan daging sapi dan babi diuji secara organoleptik menggunakan metode hedonik yang terdiri dari penilaian sensorik terhadap warna, aroma, tekstur, rasa dan kekenyalan dengan tujuan mengetahui penerimaan panelis terhadap mutu bakso rasio perbandingan daging sapi dan babi yang dihasilkan. Penilaian uji mutu hedonik yaitu uji kualitas bakso berdasarkan pengamatan panelis yang dimulai dengan skala 1 hingga skala 5 sesuai dengan penilaian sensorik yang diamati. Hasil uji organoleptik yang diperoleh dapat dilihat pada Tabel 1.

Dari tabel 1, dapat dilihat bahwa untuk parameter warna rataan tertinggi pada perlakuan P1 dan yang terendah pada kontrol bakso daging sapi. Untuk parameter aroma, rataan tertinggi diperoleh oleh Kontrol bakso daging sapi sedangkan rataan terendah diperoleh oleh P3. Untuk parameter tekstur, rataan tertinggi diperoleh oleh P2 sedangkan rataan terendah diperoleh oleh kontrol bakso sapi. Untuk parameter rasa, rataan tertinggi diperoleh oleh P1 sedangkan rataan terendah diperoleh oleh P3. Untuk parameter kekenyalan, rataan tertinggi diperoleh oleh Kontrol bakso daging babi sedangkan rataan terendah diperoleh oleh kontrol bakso danging sapi.

Berdasarkan data yang diperoleh rata-rata kesukaan panelis terhadap variabel uji organoleptik bakso yang dihasilkan dari tiap perlakuan dikategorikan netral.

\section{Warna}

Warna bakso dipengaruhi oleh warna daging yang berkaitan erat dengan kandungan mioglobin pada daging dan dipengaruhi juga oleh penambahan bahan pengisi seperti tepung serta bumbu-bumbu. Bakso babi memiliki warna yang lebih terang daripada bakso sapi.

Hasil analisis Kruskall-Wallis terhadap skor warna bakso yang diperoleh menunjukkan bahwa perlakuan rasio perbandingan daging sapi dan babi memberikan pengaruh yang nyata $(\mathrm{P}<0.05)$ (Tabel 1$)$ terhadap warna bakso yang dihasilkan dan bakso kontrol (Bakso Sapi).

Semakin tinggi nilai Kruskall-Wallis pada tiap perlakuan, menyebabkan hasil uji organoleptik terhadap semakin tinggi, sebaliknya jika nilai Kruskall-Wallis rendah maka hasil uji organoleptik semakin rendah tergantung dengan parameter yang diamati.

Berdasarkan hasil uji organoleptik dan nilai Kruskall-Wallis untuk warna bakso yang dihasikan, terlihat bahwa semakin tinggi nilai Kruskall-Wallis, menyebabkan hasil uji organoleptik untuk warna bakso yang dihasilkan baik. Bakso yang dihasilkan oleh P1, P2 dan P3 berwarna agak abu-abu sampai abu-abu. Hal ini disebabkan oleh penambahan daging babi sehingga warna bakso menjadi lebih cerah. Daging sapi memiliki kandungan mioglobin yang tinggi sehinga menghasilkan bakso yang berwarna abu-abu kehitaman, akan tetapi jika ditambahkan dengan daging babi yang memiliki kandungan mioglobin rendah, menyebabkan warna bakso yang dihasilkan menjadi lebih abu-abu. 


\section{Median Volume 13 Nomor 1 Bulan Februari 2021}

Doi http://doi.org/md.v13i1.191

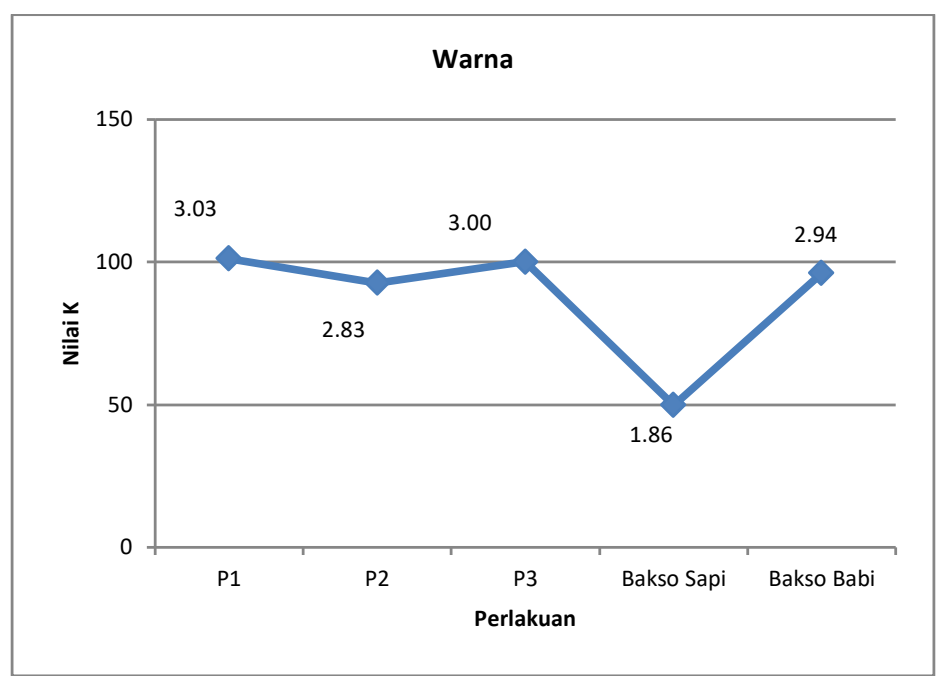

Gambar 1. Grafik Nilai Kruskal Wallis \& Uji Organoleptik Warna.

Warna bakso Perlakuan P1 dan P3 berwarna agak abu-abu dari perlakuan lainnya, yang disebabkan oleh kandungan mioglobin pada daging sapi yang tinggi sehingga memberikan penampakan warna yang lebih tua sehingga bewarna gelap, namun dengan penambahan daging babi pada bakso menjadi lebih cerah. Bakso kontrol daging babi memiliki warna pucat (cerah).

Diantara faktor-faktor yang mempengaruhi warna daging olahan, pemanasan menyebabkan daging berwarna coklat karena terjadi denaturasi globin, karamelisasi karbohidrat dan reaksi maillard gula-gula pereduksi dengan asam amino (Lewrie, 1995 dalam Hetharia, 2013). Penilaian warna bakso juga dipengaruhi oleh kandungan air adonan. Indrarmono (1987) dalam Hetharia (2013), menyatakan bahwa air mempunyai kecerahan yang sangat tinggi karena mampu membuat warna adonan menjadi lebih muda. Kadar air yang terlalau tinggi dapat menurunkan daya ikat air sehingga menyebabkan penurunan kandungan pigmen. Pigmen semakin keluar bersama dengan lepasnya cairan sel pada waktu pemasakan atau pengolahan sehingga intesitas warna menurun (Elviera, 1988 dalam Hetharia, 2013).

\section{Aroma}

Aroma bakso dipengaruhi oleh aroma daging, bahan pengisi berupa tepung tapioka serta bahan lainnya yang ditambahkan. Selama proses pengolahan (pemasakan) terjadi reaksi antara bahan pengisi dan daging, yang menyebabkan berkurangnya aroma khas dari daging sebagai bahan baku. Aroma disebut sebagai pencicipan dari jarak jauh, dapat dikenal hanya dengan mencium aromanya saja (Soekarto, 1985 dalam Irmawaty, 2010).

Proses pembuatan bakso mempengaruhi aroma bakso yang dihasilkan tergantung dari jenis pemaskaan yang digunakan serta lama maupun suhu pemasakan dalam proses pembuatan bakso. 


\section{Median Volume 13 Nomor 1 Bulan Februari 2021}

Doi http://doi.org/md.v13i1.191

Tabel 1. Rataan Uji Organoleptik terhadap Bakso Rasio Daging Ayam dan Daging Babi

\begin{tabular}{lccccc}
\hline \multirow{2}{*}{ Parameter } & \multicolumn{3}{c}{ Perlakuan } & \multicolumn{2}{c}{ Kontrol } \\
\cline { 2 - 6 } & P1 & P2 & P3 & Bakso Sapi & Bakso Babi \\
\hline Warna & $3,03^{\mathrm{a}}$ & $2,83^{\mathrm{a}}$ & $3.00^{\mathrm{a}}$ & $1,86^{\mathrm{b}}$ & $2,94^{\mathrm{a}}$ \\
Aroma & $3,26^{\mathrm{a}}$ & $3,26^{\mathrm{a}}$ & $3,11^{\mathrm{a}}$ & $3,43^{\mathrm{a}}$ & $3,29^{\mathrm{a}}$ \\
Tekstur & $3,23^{\mathrm{a}}$ & $3,54^{\mathrm{a}}$ & $3,31^{\mathrm{a}}$ & $2,97^{\mathrm{a}}$ & $3,29^{\mathrm{a}}$ \\
Rasa & $3,51^{\mathrm{a}}$ & $3,49^{\mathrm{a}}$ & $3,17^{\mathrm{a}}$ & $3,46^{\mathrm{a}}$ & $3,20^{\mathrm{a}}$ \\
Kekenyalan & $3,00^{\mathrm{a}}$ & $2,94^{\mathrm{a}}$ & $3,20^{\mathrm{a}}$ & $2,49^{\mathrm{b}}$ & $3,46^{\mathrm{a}}$ \\
\hline
\end{tabular}

Keterangan: superscript berbeda pada baris yang sama menunjukkan perbedaan yang nyata $(\mathrm{P}<0.05)$

Hal inilah yang menyebabkan perlakuan rasio antara daging sapi dengan daging babi tidak berpengaruh terhadap aroma bakso yang dihasilkan.

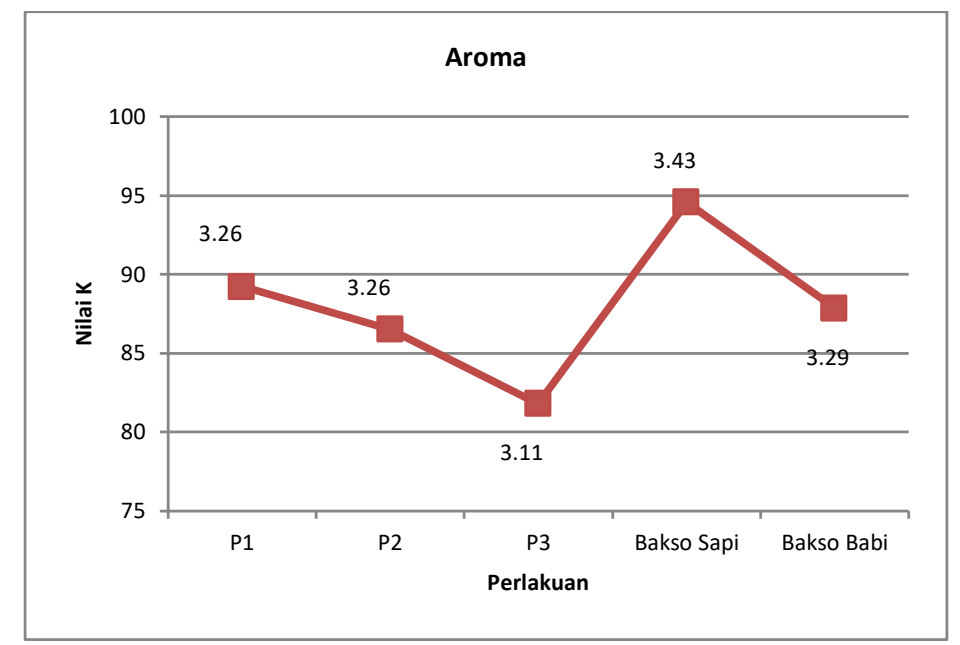

Gambar 2. Grafik Nilai Kruskal Wallis \& Uji Organoleptik Aroma.

Berdasarkan Gambar 2, menyatakan bahwa semakin tinggi nilai Kruskall-Wallis menyebabkan semakin tinggi pula nilai uji organoleptik untuk aroma bakso yang dihasilkan yaitu antara agak beraroma daging sapi dan beraroma daging sapi. Sehingga aroma bakso yang dihasilkan dari P1, P2, P3 diterima baik oleh panelis.

Rataan aroma mutu hedonik bakso berkisar antara 3.11 sampai 3.43. Berdasarkan uji Kruskall-Wallis terhadap mutu hedonik aroma menunjukkan bahwa perlakuan rasio perbandingan daging sapi dan babi tidak berpengaruh terhadap aroma bakso yang dihasilkan $(\mathrm{P}>0.05)$.

Aroma bakso dipengaruhi oleh bahan bakuserta bumbu. Bumbu dapat meningkatkan dan memodifikasi rasa. Pemberian bumbu yang berbeda menghasilkan produk daging olahan dengan rasa yang berbeda pula (Soeparno, 2009). Bumbu biasanya diberikan dalam bentuk halus karena digiling atau diekstrasi. Bumbu yang digiling lebih mudah terdispersi dibandingkan dalam bentuk utuh (Judge et al, 1989 dalam Soeparno, 2009). Bumbu adalah bahan tambahan yang gunakan dengan sengaja untuk meningkatkan cita rasa (Winarno et al, 1980). Rempah-rempah bermanfaat untuk 


\section{Median Volume 13 Nomor 1 Bulan Februari 2021}

Doi http://doi.org/md.v13i1.191

meningkatkan cita rasa dan berfungsis sebagai antioksidan serta anti mikroba yang berguna untuk memperpanjang masa simpan bakso.

\section{Tekstur}

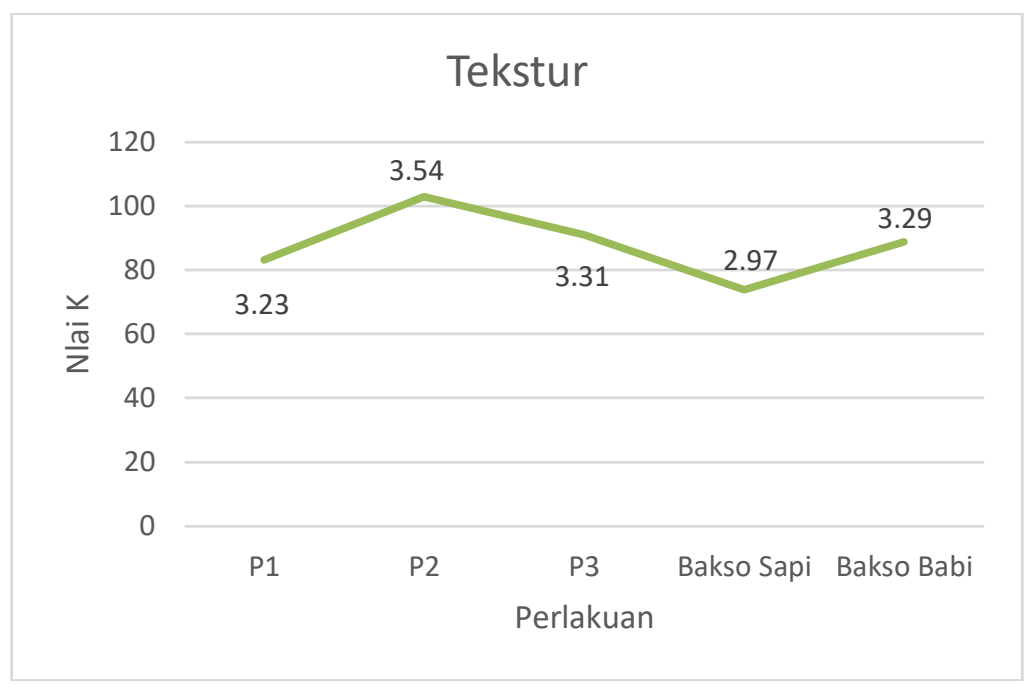

Gambar 3. Grafik Nilai Kruskal Wallis \& Uji Organoleptik Tekstur.

Gambar 3, menyatakan bahwa semakin tinggi nilai Kruskal Wallis maka semakin tinggi pula nilai organoleptik untuk parameter tekstur dari baksi yang dihasilkan. Berdasarkan hasil analisis tekstur bakso yang dihasilkan berkisar dari kasar-halus. Dengan demikian semakin tinggi nilai Kruskal-Wallis maka semakin baik penilaian terhadap uji organoleptik yang dihasilkan.

Hasil analisis Kruskal-wallis terhadap skor tekstur bakso yang diperoleh menunjukkan bahwa perlakuan rasio perbandingan daging sapi dan babi tidak berpengaruh nyata terhadap tekstur bakso $(\mathrm{P}>0.05)$. Tingginya kandungan jaringan ikat dalam daging menyebabkan tekstur produk olahan daging yang kasar dan liat. Semakin tinggi jaringan ikat maka semakin sulit untuk digiling sampai halus sehingga tekstur yang dihasilkan semakin kasar. Menurut Smyth et al (1996), tekstur daging hasil olahan sangat dipengaruhi oleh proses penggumpalan protein selama pemanasan.

\section{Rasa}

Rasa merupakan kompenen penentu daya terima suatu produk oleh konsumen. Rasa suatu makanan terbentuk oleh rangsangan dari aroma dan warna makanan tersebut. Ada tiga rasa yang sangat menentukan bakso bisa diterima oleh konsumen yaitu kegurihan, keasinan dan rasa daging (Berutu dkk, 2010). Berdasarkan hasil uji organoleptik, perlakuan rasio perbandingan daging sapi dan babi. Tiding berpengaruh terhadap rasa baksio yang dihasilkan $(\mathrm{P}>0.05)$. 


\section{Median Volume 13 Nomor 1 Bulan Februari 2021}

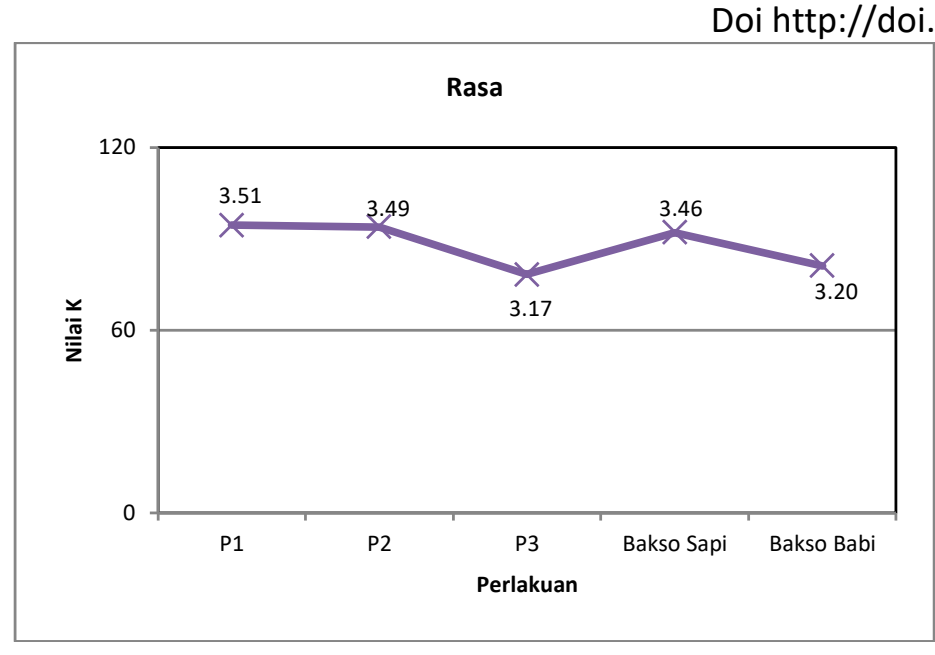

Gambar 4. Grafik Nilai Kruskal Wallis \& Uji Organoleptik Rasa.

Gambar 4, menyatakan bahwa semakin tinggi nilai Kruskal Wallis maka semakin tinggi pula nilai organoleptik untuk parameter rasa dari bakso yang dihasilkan. Berdasarkan hasil analisis rasa bakso yang dihasilkan berkisar dari agak berasa daging sapi - berasa daging sapi. Dengan demikian semakin tinggi nilai Kruskal-Wallis maka semakin baik penilaian terhadap uji organoleptik yang dihasilkan.

Bakso yang berasal dari kondisi daging pre rigor akan memiliki rasa yang lebih baik, karena daging pada kondisi ini mempunyai daya ikat air dan $\mathrm{pH}$ yang tinggi sehingga dapat meningkatkan keempukan dan juicy pada daging (Soeparno, 2009). Formulasi antara kondisi daging sebagai baahan baku utama ditambah dengan tepung sebagai bahan pengisi serta bumbu dan bahan lainnya sangat mempengaruhi rasa bakso yang dihasilkan.

Peramuan rasa itu sendiri merupakan suatu hal yang dapat membuat seseorang untuk dapat menentukan tingkat nilai kepuasan setelah menikmatinya. Lidah merupakan indera yang paling banyak terlibat dalam uji rasa, lidah bekerja untuk menilai suatu rasa dengn cara mengetahui kelarutan makanan tersebut dengan saliva dan kontak dengan saraf perasa.

\section{Kekenyalan}

Hasil uji organoleptik kekenyalan bakso berdasarkan uji Kruskall-Wallis dipengaruhi $(\mathrm{P}<0.05)$ oleh perlakuan rasio perbandingan daging sapi dan babi. Kekenyalan mempengaruhi palatabilitas seseorang terhadap penilaian kekenyalan produk. Kekenyalan juga dipengaruhi oleh kemudahan pada saat mengunyah tanpa menghilangkan sifat jaringan.

Gambar 5, menyatakan bahwa semakin tinggi nilai Kruskal Wallis maka semakin tinggi pula nilai organoleptik untuk parameter kekenyalan dari bakso yang dihasilkan. Berdasarkan hasil analisis tekstur bakso yang dihasilkan berkisar dari agak kenyal kenyal. Dengan demikian semakin tinggi nilai Kruskal-Wallis maka semakin baik penilaian terhadap uji organoleptic yang dihasilkan. 


\section{Median Volume 13 Nomor 1 Bulan Februari 2021}

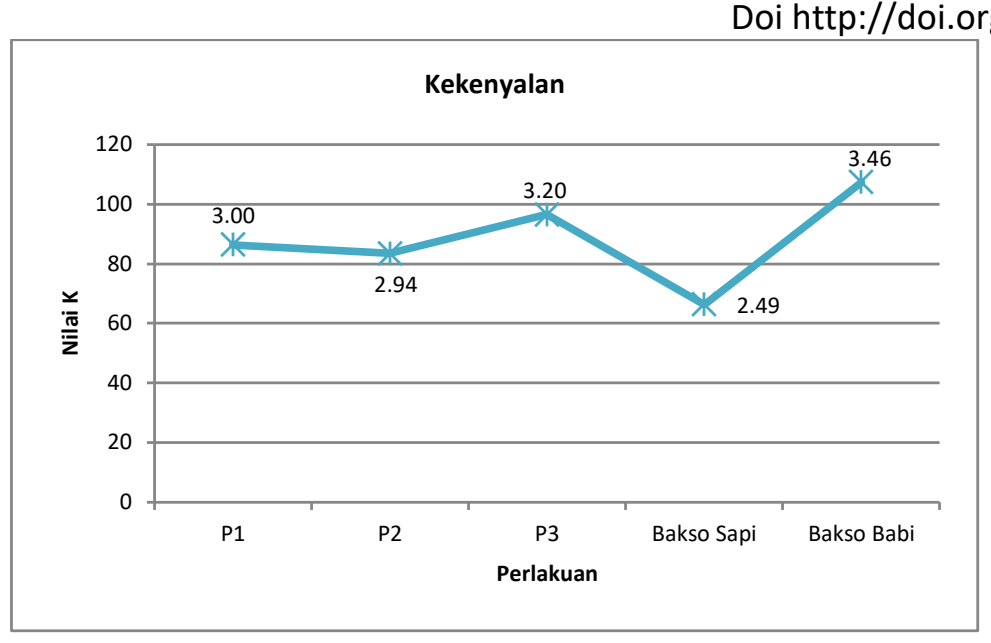

Gambar 5. Grafik Nilai Kruskal Wallis \& Uji Organoleptik Kekenyalan.

Lawrie, (2003) menyatakan bahwa kekenyalan melibatkan kemudahan gigi mengunyah bakso menjadi potongan-potongan yang kecil dengan meninggalkan residu selama proses pengunyahan (Lawrie, 2003). Kekenyalan bakso dipengaruhi oleh struktur daging yang bisa mengikat air sehingga bisa dikunyah. Struktur daging babi yang longgar dapat meningkatkan kemampuan mengikat air pada bakso, sehingga menghasilkan bakso yang kenyal tidak mudah pecah bila ada tekanan, sehingga daya ikat air juga mempengaruhi kekenyalan bakso.

Daya ikat air adalah kemampuan daging untuk mempertahankan kandungan airnya selama mengalami berbagai proses pengolahan. Semakin tinggi daya ikat air, semakin tinggi pula kandungan protein yang dapat meningkatkan kekenyalan bakso. Hal ini menyebabkan tingginya persentase air yang terikat dalam produk yang berpengaruh kepada besarnya daya mengikat air.

\section{KESIMPULAN}

Hasil uji organoleptik menunjukkan bahwa perlakuan rasio perbandingan daging sapi dan babi memberikan pengaruh yang nyata terhadap sifat organoleptik warna dan kekenyalan tetapi tidak berpengaruh terhadap sifat organoleptik aroma, rasa dan tekstur. Berdasarkan uji organoleptik, panelis lebih menyukai keseluruhan parameter pada bakso dengan rasio antara daging sapi 50\% dan daging babi 50\%. Bagi produsen bakso dapat menambah daging babi hingga taraf $50 \%$ untuk pembuatan bakso. Perlu pengamatan lebih lanjut pada aspek kimia bakso dari penelitian ini

\section{DAFTAR PUSTAKA}

Abustam, E, J.C.Likadja dan A. Ma'arif. 2009. Penggunaan Asap Cair sebagai Bahan Pengikat pada Pembuatan Bakso Daging Sapi Bali. Prosiding Seminar Nasional Kebangkitan peternakan. Program Magister Ilmu Ternak Pascasarjana Fakultas Peternakan Universitas Diponegoro.Badan Penerbit Universitas Diponegoro. 


\section{Median Volume 13 Nomor 1 Bulan Februari 2021}

Doi http://doi.org/md.v13i1.191

Berutu, K.M., E. Suryanto dan R. Utomo. 2010. Kualitas Bakso Daging Sapi Peranakan Ongole yang Diberi Pakan Basal Tongkol Jagung dan Undergraded Protein dalam Complete Feed. Buletin Peternakan, 34(2), 103-113.

Hetharia, Ch. 2013. Kajian Bakso Berbahan dasar Daging Babi dan Ulat Sagu sebagai Sumber protein dengan bahan pengikat tepung sagu. Tesis. Program Studi Magister Ilmu Ternak. Fakultas Peternakan dan Pertanian Universitas Diponegoro. Semarang.

Irmawaty. 2016. Uji Organoleptik Bakso Daging Ayam Dengan Filler Tepung Sagu (Metroxylon sago rottb) pada Konsentrasi Berbeda. JIP-Jurnal Ilmu dan Indutri Peternakan, 3(1), 182-193

Nordiansyah Firahmi, Siti Dharmawati dan Mofie Aldrin. 2015. Sifat Fisik Dan Organoleptik Bakso Yang Dibuat Dari Daging Sapi Dengan Lama Pelayuan Berbeda. Ulum Sains dan Teknologi, 1(1), 39-45.

Rahmatina. 2010. Sifat Fisik Dan Organoleptik Bakso berbagai Rasio Antara Daging Sapi dan Daging Ayam. Fakultas Peternakan. Departemen Ilmu Produksi Dan Teknologi Peternakan. Institut Pertanian Bogor. https://fdokumen.com/document/sifat-fisikdan-organoleptik-bakso-pada-berbagai-daging-sapi-dan-daging-ayam.html

Soekarto, S.T. 1985. Penilaian Organoleptik Pusat Pengembangan Teknologi Pangan. Institut Pertanian Bogor. Press Bogor

Soeparno. 2009. Ilmu dan Teknologi Daging. Yogyakarta. Gadjah Mada University Press.

Sunarlim, R. 2000. Penggunaan Berbagai Konsentrasi Nacl Dan Jenis Daging Terhadap Mutu Bakso. Prosiding Seminar Nasional Teknologi Inovatif Pascapanen untuk Pengembangan lndustri Berbasis Pertanian. Balai Besar Penelitian dan Pengembangan Pascapanen Pertanian. 408-418.

Lawrie, R.A. 2003. Ilmu Daging. Edisi Kelima. Penerjemah Aminuddin Parakkasidan Yudha Amwila. Penerbit Universitas Indonesia Jakarta. UI-Press 